\title{
ANALISIS KEYAKINAN DIRI (SELF EFFICACY) AKADEMIK DAN POLA ASUH ORANG TUA TERHADAP KEMANDIRIAN BELAJAR SISWA MATA PELAJARAN EKONOMI KELAS X SMA NEGERI 1 TULUNGAGUNG TAHUN PELAJARAN 2017/2018
}

\author{
Reva Rey Valentin ${ }^{1}$, Nafik Umurul Hadi ${ }^{1}$ \\ ${ }^{1}$ Program Studi Pendidikan Ekonomi - STKIP PGRI Tulungagung \\ e-mail: ${ }^{1}$ revareyvalentin@gmail.com, ${ }^{1}$ nafikumurulhadi@gmail.com
}

\begin{abstract}
Abstrak
Kemandirian belajar merupakan salah satu aspek penting guna mencapai keberhasilan belajar. Mengingat peserta didik akan selalu dihadapkan pada situasi dan dinamika kehidupan yang dinamis serta berkembang, terlebih dengan ditunjang oleh perkembangan teknologi dan arus global yang semakin sulit sehingga peserta didik akan semakin didesak kearah kehidupan yang lebih kompetitif. Sehingga masalah kemandirian belajar yang rendah harus segera diatasi agar tidak menjadi kebiasaan buruk dan berdampak negatif bagi peserta didik. Penelitian ini bertujuan untuk menganalisis pengaruh secara parsial dan simultan keyakinan diri (self efficacy) akademik dan pola asuh orang tua terhadap kemandirian belajar. Penelitian ini merupakan penelitian kuantitatif korelasi. Teknik analisis data yang digunakan adalah analisis regresi linier berganda. Hasil penelitian menunjukkan bahwa: (1) ada pengaruh yang signifikan antara keyakinan diri (self efficacy) akademik terhadap kemandirian belajar dengan nilai $t_{\text {hitung }}$ dari $\mathrm{X}_{1}$ terhadap $\mathrm{Y}$ senilai $\mathrm{t}_{\text {hitung }}$ $(6,004)>t_{\text {tabel }}(1,996)$. (2) ada pengaruh yang signifikan antara pola asuh orang tua terhadap kemandirian belajar dengan nilai thitung dari $\mathrm{X}_{2}$ terhadap $\mathrm{Y}$ senilai thitung $(5,218)>$ $t_{\text {tabel }}(1,996)$. (3) ada pengaruh yang signifikan antara keyakinan diri (self efficacy) akademik dan pola asuh orang tua terhadap kemandiran belajar dengan nilai $F_{\text {hitung }}(59,073)$ $>\mathrm{F}_{\text {tabel }}(3,13)$.
\end{abstract}

Kata Kunci: keyakinan diri (self efficacy) akademik, pola asuh orang tua, kemandirian belajar

\section{PENDAHULUAN}

Pendidikan merupakan hal penting bagi kelangsungan kehidupan bangsa. Hal tersebut dikarenakan kualitas kehidupan suatu bangsa erat kaitannya dengan tingkat pendidikan. Kualitas dari suatu pendidikan dapat dilihat dari keberhasilan belajar peserta didik, hal tersebut ditunjukkan dari prestasi belajar yang dicapai oleh peserta didik. Keberhasilan peserta didik dalam belajar secara optimal dilakukan dengan penuh kemandirian. Kemandirian peserta didik pada umumnya dikaitkan dengan kemampuan peserta didik dalam melakukan segala hal sendiri. Peserta didik yang memiliki sikap mandiri akan mampu menyesuaikan diri dengan keadaan lingkungannya dan dapat mengatasi kesulitan yang dihadapinya. Dalam hal ini yang dimaksudkan kemandirian yaitu kemandirian belajar yang dijalani oleh peserta didik. Menurut D. Z. Putri (2015: 5) mengemukakan "kemandirian dalam belajar dapat diartikan sebagai aktivitas belajar dan berlangsungnya lebih didorong 
oleh kemauan sendiri, pilihan sendiri dan tanggung jawab sendiri dari siswa. Siswa yang memiliki kemandirian belajar, tidak akan terus menerus tergantung pada materi yang diberikan oleh guru dikelas".

Menurut A. K. Sari, Muhsin, \& Rozi (2017: 927) perkembangan kemandirian remaja menuju kearah kesempurnaan menjadi sangat penting untuk diikhtiarkan secara serius, sistematis, dan terprogram. Sebab problema kemandirian sesungguhnya bukan hanya merupakan masalah dalam generasi, tetapi juga masalah antar generasi. Usaha yang dilakukan dalam pendidikan untuk mengembangkan kemandirian menjadi sangat penting agar tidak terjadi gejala-gejala negatif yang dapat menjauhkan individu dari kemandirian seperti perilaku ketergantungan dan sikap tidak peduli terhadap lingkungan hidup.

Menurut Haris Mudjiman (2007, seperti dikutip Febriani, 2016: 2.356) peserta didik yang memiliki kemandirian belajar cenderung lebih aktif dibandingkan peserta didik yang kurang memiliki kemandirian belajar. Hal ini terjadi karena peserta didik dengan kemandirian belajar yang tinggi selalu memiliki inisiatif untuk mencari pengalaman baru melalui kegiatan belajar dengan atau tanpa bantuan dari guru professional.

Peserta didik seringkali kehilangan semangat belajar ketika mengalami atau menemui kesulitan dalam proses belajarnya. Banyaknya peserta didik yang belum mampu mengatasi kesulitan dalam proses belajar yang dialaminya, hal tersebut dikarenakan kemandirian belajar peserta didik masih tergolong rendah. Menurut Hasyim (2013: 3) menyatakan "rendahnya kemandirian belajar siswa ditunjukkan oleh kurangnya rasa tanggung jawab siswa dalam belajar dan mengerjakan tugas, kurang ulet saat menghadapi kesulitan belajar dan kurang kreatif dalam mengerjakan tugas".

Pada umumnya peserta didik yang memiliki kemandirian belajar rendah lebih memilih jalan pintasan yang bersifat instans atau cenderung melakukan kecurangan akademik seperti copy paste dan menyontek (baik ujian maupun dalam mengerjakan tugas) pekerjaan temannya untuk mencapai tujuan dalam belajar. Data survey atau penelitian kecurangan akademik yang dilakukan oleh peserta didik dapat dilihat pada tabel 1 sebagai berikut :

Tabel 1. Data Survey atau Penelitian Kecurangan Akademik

\begin{tabular}{clcc}
\hline No. & \multicolumn{1}{c}{ Survey atau Penelitian } & Responden & $\begin{array}{c}\text { Kecurangan } \\
\text { Akademik (\%) }\end{array}$ \\
\hline 1. & $\begin{array}{l}\text { Survey Litbang Media Group (2007) } \\
\text { (Desriana Rizki, 2015, seperti dikutip Widianto, 2016: 5) }\end{array}$ & 480 responden \\
\hline 2. & $\begin{array}{l}\text { Survey Josephson Institute of Ethics } \\
\text { (Taylor, seperti dikutip Fredrika \& Prasetyawati, 2013: 2, } \\
\text { dalam Ferguson, 2010) }\end{array}$ & 12.000 responden & $74 \%$ \\
\hline 3. & $\begin{array}{l}\text { Penelitian Bowers (1964, seperti dikutip Murdiansyah, } \\
\text { Sudarma, \& Nurkholis, 2017: 122, dalam Mc Cabe } \text { et al, } \\
\text { 2001) }\end{array}$ & 5.000 responden & $75 \%$ \\
\hline \multicolumn{1}{c}{ Rata-rata } & \\
\hline
\end{tabular}

Sumber Data : Olahan Peneliti 2018

Hal serupa ditemukan peneliti selama melakukan Magang. Berdasarkan temuan peneliti pada saat Magang di SMA Negeri 1 Tulungagung khususnya kelas X mata pelajaran ekonomi masih banyak peserta didik yang belum mencapai kemandirian belajar. Hal tersebut dapat dilihat disaat proses belajar mengajar dari sebagian besar peserta didik bergantung pada guru saat pembelajaran, masih ada peserta didik yang tidak mencatat hal-hal penting, kurang antusias/pasif dalam pembelajaran mereka lebih memilih diam walaupun sebenarnya mereka belum memahami materi yang dibahas, tidak memiliki inisiatif untuk berlatih mengerjakan soal-soal sendiri terlebih dahulu, sumber belajarnya hanya berpatokan pada LKS (Lembar Kerja Siswa) tidak memanfaatkan buku paket. Sehingga mengakibatkan banyaknya peserta 
didik yang mencari jalan pintasan atau cederung melakukan kecurangan akademik seperti copy paste dan menyontek saat ujian maupun mengerjakan tugasnya demi tercapainya tujuan belajar. Hal tersebut menunjukkan bahwa kemandirian belajar peserta didik rendah karena kemandirian belajar berpengaruh pada keberhasilan belajar/prestasi belajar.

Salah satu faktor yang mempengaruhi kemandirian belajar adalah keyakinan diri (self effiacay) akademik. Kepercayaan/keyakinan diri akademik adalah keyakinan yang dirasakan individu tentang kemampuannya dalam mengerjakan tugas-tugas keilmuan untuk membentuk perilaku yang relevan (Hasbullah \& Boon, 2015: 3). Menurut Sunawan (2005, seperti dikutip Widiyanto, 2013: 4) menyatakan bahwa berbagai studi menunjukkan self efficacy berpengaruh terhadap motivasi, keuletan dalam menghadapi kesulitan dari suatu tugas dan prestasi belajar.

Peserta didik yang memiliki keyakinan diri (self efficacy) akademik yang tinggi lebih percaya diri dalam menyelesaikan tugas-tugas yang dihadapinya sebab peserta didik tersebut yakin akan kemampuan yang dimilikinya. Peserta didik yang memiliki keyakinan diri rendah merasa tidak yakin bahwa mereka dapat menyelesaikan tugas-tugasnya, sehingga peserta didik berusaha menghindari tugas-tugas tersebut dan suka memilih jalan pintasan atau cenderung melakukan kecurangan akademik tetapi memungkinkan dialami juga oleh peserta didik yang berbakat.

Menurut Hasyim (2013: 3-4) untuk mencapai kemandirian belajar, siswa dituntut dapat memahami dirinya, menerima dirinya, mengarahkan dirinya dan mengaktualisasikan dirinya. Artinya, siswa perlu memahami kemampuan dirinya dalam belajar, baik kelebihan maupun kekurangannya. Oleh karena itu, keyakinan akan kemampuan yang dimiliki oleh siswa (self efficacy) harus diperhatikan oleh guru dalam melaksanakan pembelajaran disekolah.

Selain keyakinan diri (self efficacy) akademik, kemandirian belajar pada peserta didik juga dipengaruhi oleh pola asuh orang tua dalam keluarganya sendiri. Menurut Desywidowati, Rohmad, \& CH (2013: 6) pola asuh orang tua adalah suatu keseluruhan interaksi antara orang tua dengan anak, dimana orang tua bermaksud menstimulasi anaknya dengan mengubah tingkah laku, pengetahuan serta nilai-nilai yang dianggap paling tepat oleh orang tua, agar anak dapat mandiri, tumbuh dan berkembang secara sehat dan optimal.

Pola asuh orang tua memiliki peran yang cukup besar dalam membentuk perilaku maupun kemandirian peserta didik. Orang tua berperan mengasuh, membimbing, membantu dan mengarahkan anak agar dapat menjadi lebih mandiri. Hal tersebut sejalan dengan pendapat Nurwahyuni (2013: 68-69) pola asuh orang tua merupakan faktor yang dapat berpengaruh terhadap kemandirian belajar siswa karena lingkungan keluarga yang di dalamnya terdapat orang tua yang berperan penuh dan memberi pendidikan awal sebelum menempuh pendidikan formal. Sebelum peserta didik memasuki suatu sekolah, peserta didik sudah mendapatkan pendidikan dari orang tuanya.

Meskipun dunia pendidikan juga turut berperan memberikan kesempatan pada anak untuk mandiri tetapi pola asuh orang tua merupakan pilar utama untuk membentuk anak menjadi mandiri. Jika orang tua sebagai pendidik yang pertama dan utama tidak berhasil meletakkan dasar kemandirian pada anaknya maka akan sangat sulit berharap sekolah mampu membentuk anak menjadi mandiri. Orang tua seharusnya lebih memperhatikan bagaimana pengaruh pola asuh yang mereka berikan terhadap kemandirian belajar yang dijalani anaknya sehingga kemandirian belajar anaknya lebih terarah dan meminimalisir adanya kecenderungan memilih jalan pintasan atau kecurangan akademik. Latar belakang keluarga yang berbeda akan membentuk pola asuh orang tua yang berbeda pula pada anak.

Keyakinan diri (self efficacy) akademik dan pola asuh orang tua diduga berpengaruh terhadap kemandirian belajar siswa mata pelajaran ekonomi kelas X SMA Negeri 1 
Tulungagung. Hal ini didasari/diperkuat oleh beberapa penelitian terdahulu, yang dilakukan oleh Apriani Kartika Sari, Muhsin, Fahrur Rozi (2017) yang berjudul "Pengaruh Motivasi, Sarana Prasarana, Efikasi Diri, dan Penyesuaian Diri terhadap Kemandirian Belajar" dengan menyatakan bahwa ada pengaruh yang signifikan antara motivasi, sarana prasarana, efikasi diri dan penyesuaian diri terhadap kemandirian belajar siswa administrasi perkantoran SMK YPE Nusantara Slawi. Semakin tinggi motivasi, sarana prasarana, efikasi diri dan penyesuaian diri siswa maka semakin tinggi pula kemandirian belajar siswa begitu pula sebaliknya. Penelitian ini juga didasari oleh penelitian yang dilakukan oleh Fahrizal Efendhi (2014) yang berjudul "Pengaruh Pola Asuh Orang Tua terhadap Kemandirian dalam Belajar Siswa" dengan hasil ada pengaruh yang signifikan antara pola asuh orang tua terhadap kemandirian siswa dalam belajar. Semakin baik pola asuh orang tua terhadap siswa, maka akan semakin baik tingkat kemandirian siswa begitu pula sebaliknya. Penelitian ini juga didasari oleh penelitian yang dilakukan oleh Ika Aprilia, Sri Witurachmi dan Nurhasan Hamidi (2017) yang berjudul "Pengaruh Self-Efficacy dan Motivasi Berprestasi terhadap Kemandirian belajar Siswa pada Mata Pelajaran Produktif Akuntansi" dengan hasil ada pengaruh yang positif dan signifikan Self-Efficacy dan motivasi berprestasi terhadap kemandirian belajar siswa pada mata pelajaran produktif akuntansi. Semakin tinggi SelfEfficacy dan motivasi berprestasi siswa maka semakin tinggi pula kemandirian belajar siswa pada mata pelajaran produktif akuntansi begitu pula sebaliknya. Penelitian ini juga didasari oleh penelitian yang dilakukan oleh Enda Dian Rahnawati (2013) yang berjudul "Pengaruh Pola Asuh Orang Tua terhadap Kemandirian Belajar Siswa Kelas XI TSM SMK N 8 Purworejo" dengan hasil pola asuh orang tua memberikan pengaruh yang signifikan terhadap kemandirian belajar. Semakin baik pola asuh orang tua terhadap anaknya maka semakin baik pula kemandirian belajar anak begitu pula sebaliknya. Dan penelitian ini juga didasari oleh penelitian yang dilakukan Venny Febriani (2016) yang berjudul "Pengaruh Efikasi Diri dan Regulasi Diri terhadap Kemandirian Belajar Siswa Pada Mata Pelajaran IPS" dengan hasil efikasi diri dan regulasi diri berpengaruh signifikan terhadap kemandirian belajar siswa. Semakin tinggi efikasi diri dan regulasi diri maka semakin tinggi pula kemandirian belajar siswa begitu pula sebaliknya.

Data lulusan SMA/SMU/SMK dapat dilihat pada tabel 2 dibawah ini:

Tabel 2. Data Lulusan SMA/SMU/SMK

\begin{tabular}{|c|c|c|c|c|c|c|c|c|}
\hline \multirow{3}{*}{$\begin{array}{l}\text { Pendidikan } \\
\text { yang } \\
\text { Ditamatkan }\end{array}$} & \multicolumn{8}{|c|}{ Tahun Lulus } \\
\hline & \multicolumn{2}{|c|}{2014} & \multicolumn{2}{|c|}{2015} & \multicolumn{2}{|c|}{2016} & \multicolumn{2}{|c|}{2017} \\
\hline & Feb & Agt & Feb & Agt & Feb & Agt & Feb & $\mathrm{Agt}$ \\
\hline SMA/SMU & 1.893 .509 & 1.962 .766 & 762.411 & 2.280 .029 & 546.699 & 1.950 .62 & 1.552 .894 & 1.910 .829 \\
\hline SMK & 847.365 & & 1.174 .366 & 1.569 .690 & 48.327 & 20. & 1.383 .022 & 1.621 .402 \\
\hline Total & 2.740 .874 & 3.295 .287 & 2.936 .777 & 3.849 .719 & 2.895 .026 & 3.471 .175 & 2.935 .916 & 3.532 .231 \\
\hline
\end{tabular}

Sumber Data : BPS (Badan Pusat Statistik), 2017

Data nilai peserta didik kelas X-1 sampai X-7 dapat dilihat pada tabel 3 dibawah ini :

Tabel 3. Data Nilai Peserta Didik Kelas X-1 sampai X-7

\begin{tabular}{cccccccccc}
\hline No & Aspek & KKM & \multicolumn{7}{c}{ Rata-Rata Nilai Kelas } \\
\cline { 3 - 9 } & & & X-1 & X-2 & X-3 & X-4 & X-5 & X-6 & X-7 \\
\hline 1. & UH 1 & 75 & 75,23 & 77,55 & 76,35 & 76,79 & 76,65 & 77,56 & 76,24 \\
\hline 2. & Tugas 1 & 75 & 82,58 & 81,78 & 82,78 & 83,59 & 81,94 & 84,84 & 80 \\
\hline 3. & UH 2 & 75 & 77,4 & 75,81 & 75,94 & 76,88 & 76,09 & 76,38 & 75,91 \\
\hline 4. & Tugas 2 & 75 & 85,19 & 84,28 & 80,87 & 85,91 & 84,48 & 82,34 & 84,48 \\
\hline 5. & UTS & 75 & 76,63 & 77,55 & 76 & 76,97 & 75,75 & 77,64 & 76,26 \\
\hline
\end{tabular}

Sumber Data : SMA Negeri 1 Tulungagung, 2017/2018

Berdasarkan fakta dan pendapat penulis diatas menunjukkan bahwa kemandirian 
belajar merupakan salah satu aspek penting guna mencapai keberhasilan belajar. Kemandirian belajar menarik untuk diteliti mengingat peserta didik akan selalu dihadapkan pada situasi dan dinamika kehidupan yang dinamis serta berkembang. Terlebih dengan ditunjang oleh perkembangan teknologi dan arus global yang semakin sulit sehingga peserta didik akan semakin didesak kearah kehidupan yang lebih kompetitif. Sehingga masalah kemandirian belajar yang rendah harus segera diatasi agar tidak menjadi kebiasaan buruk dan berdampak negatif bagi peserta didik. Sehingga dengan alasan tersebut peneliti tertarik untuk mengadakan penelitian dengan judul "Analisis Keyakinan Diri (Self Efficacy) Akademik dan Pola Asuh Orang Tua terhadap Kemandirian Belajar Siswa Mata Pelajaran Ekonomi Kelas X SMA Negeri 1 Tulungagung Tahun Pelajaran 2017/2018”.

Rumusan masalah penelitian ini adalah: (1) Adakah pengaruh keyakinan diri (self efficacy) akademik terhadap kemandirian belajar ?. (2) Adakah pengaruh pola asuh orang tua terhadap kemandirian belajar ?. Dan (3) Adakah pengaruh keyakinan diri (self efficacy) akademik dan pola asuh orang tua terhadap kemandirian belajar ?.

Tujuan dilakukannya penelitian ini adalah: (1) Untuk menganalisis pengaruh keyakinan diri (self efficacy) akademik terhadap kemandirian belajar. (2) Untuk menganalisis pengaruh pola asuh orang tua terhadap kemandirian belajar. Dan (3) Untuk menganalisis pengaruh keyakinan diri (self efficacy) akademik dan pola asuh orang tua terhadap kemandirian belajar.

\section{METODE}

Penelitian ini merupakan jenis penelitian kuantitatif korelasi. Menurut Sugiyono (2015: 14), "penelitian kuantitatif adalah penelitian yang berlandaskan pada filsafat positivism, digunakan untuk meneliti pada populasi atau sampel tertentu, pengumpulan data menggunakan instrumen penelitian, analisis data yang bersifat kuantitatif/statistik, dengan tujuan untuk menguji hipotesis yang telah ditetapkan". Menurut Arikunto (2010: 4) penelitian korelasi yaitu penelitian yang dilakukan untuk mengetahui hubungan antara dua variabel atau lebih tanpa melakukan perubahan, tambahan atau manipulasi terhadap data yang memang sudah ada. Rancangan penelitian kuantitatif ini merupakan rancangan penelitian noneksperimen yaitu rancangan penelitian yang memotret variabel secara apa adanya.

Menurut Sujarweni (2014: 87) definisi operasional adalah variabel penelitian dimaksudkan untuk memahami arti setiap variabel penelitian sebelum dilakukan analisis. Untuk mendapatkan persamaan persepsi/kejelasan pemahaman terhadap makna variabel yang dimaksud dalam penelitian, maka peneliti menguraikan sebagai berikut :

1. Kemandirian Belajar (Y)

Kemandirian belajar adalah suatu aktivitas belajar yang didorong oleh kemauan sendiri, pilihan sendiri dan tanggung jawab sendiri dari siswa tanpa tergantung pada orang lain demi mencapai tujuan belajar.

2. Keyakinan Diri (Self Efficacy) Akademik $\left(\mathrm{X}_{1}\right)$

Keyakinan diri (self efficacy) akademik adalah keyakinan pada kemampuan diri individu untuk melaksanakan dan menyelesaikan berbagai tugas-tugas yang dihadapi sehingga dapat mengatasi rintangan untuk mencapai keberhasilan akademik.

3. Pola Asuh Orang Tua $\left(\mathrm{X}_{2}\right)$

Pola asuh orang tua adalah keseluruhan interaksi orang tua terhadap anaknya dalam hal mendidik, membimbing, mendisiplinkan serta melindungi anak agar anak dapat mandiri, tumbuh dan berkembang secara sehat dan optimal.

Variabel yang dikaji dalam penelitian adalah keyakinan diri (self efficacy) akademik $\left(\mathrm{X}_{1}\right)$, pola asuh orang tua $\left(\mathrm{X}_{2}\right)$ dan kemandirian belajar $(\mathrm{Y})$. Populasi dalam penelitian ini adalah seluruh siswa kelas X SMA Negeri 1 Tulungagung tahun pelajaran 2017/2018 yang 
terdiri dari 7 kelas dengan jumlah 233 siswa. Teknik sampling yang digunakan dalam penelitian ini adalah Proportional Random Sampling dengan jumlah sampel sebanyak 70 siswa. Teknik pengumpulan data yang digunakan adalah kuesioner atau angket dan dokumentasi. Penelitian ini menggunakan kuesioner atau angket sebagai pengumpul data yang akan diambil dari variabel keyakinan diri (self efficacy) akademik, pola asuh orang tua dan kemandirian belajar. Skala pengukuran kuesioner atau angket ini menggunakan skala Likert. Sedangkan dokumentasi digunakan untuk mengetahui nama siswa dan jumlah siswa kelas X SMA Negeri 1 Tulungagung tahun pelajaran 2017/2018. Sebelum angket digunakan dalam penelitian dilakukan uji validitas dan uji reliabilitas. Uji validitas menggunakan rumus Product Moment, sedangkan uji reliabilitas menggunakan rumus Cronbach's Alpha. Sebelum melaksanakan analisis regresi linier berganda, maka terlebih dahulu dilakukan persyaratan linear berganda atau yang disebut uji asumsi klasik (meliputi : uji normalitas, uji linieritas, uji multikolinearitas dan uji heteroskedastisitas). Teknik analisis data yang digunakan dalam penelitian ini adalah analisis regresi linier berganda selanjutnya dilakukan uji hipotesis yaitu uji $\mathrm{t}$ (parsial) dan uji $\mathrm{F}$ (simultan) dengan menggunakan program SPSS versi 16.0 for windows. Analisis regresi linier berganda digunakan untuk membuktikan sejauh mana pengaruh keyakinan diri (self efficacy) akademik dan pola asuh orang tua terhadap kemandirian belajar.

\section{HASIL DAN PEMBAHASAN}

\section{A. Hasil Penelitian}

Berdasarkan analisis deskriptif variabel kemandirian belajar pada umumnya berada pada kategori baik dengan persentase 75,71\%, variabel keyakinan diri (self efficacy) akademik pada umumnya berada pada kategori baik dengan persentase $70 \%$, dan variabel pola asuh orang tua pada umumnya berada pada kategori baik dengan persentase $72,86 \%$.

\section{Analisis Regresi Linier Berganda}

Analisis regresi digunakan untuk mengetahui sejauh mana pengaruh keyakinan diri (self efficacy) akademik dan pola asuh orang tua terhadap kemandirian belajar siswa mata pelajaran ekonomi kelas X SMA Negeri 1 Tulungagung tahun pelajaran 2017/2018. Sedangkan pada penelitian ini analisis yang digunakan adalah analisis regresi linier berganda. Hasil analisis regresi linier berganda adalah sebagai berikut:

Tabel 4. Regresi Linier Berganda

Coefficients $^{\mathrm{a}}$

\begin{tabular}{|c|c|c|c|c|c|}
\hline \multirow[b]{2}{*}{ Model } & \multicolumn{2}{|c|}{$\begin{array}{l}\text { Unstandardized } \\
\text { Coefficients }\end{array}$} & \multirow{2}{*}{$\begin{array}{c}\begin{array}{c}\text { Standardized } \\
\text { Coefficients }\end{array} \\
\text { Beta }\end{array}$} & \multirow[b]{2}{*}{$\mathrm{T}$} & \multirow[b]{2}{*}{ Sig. } \\
\hline & B & Std. Error & & & \\
\hline $1 \quad$ (Constant $)$ & 11.765 & 6.183 & & 1.903 & .061 \\
\hline $\begin{array}{l}\text { Keyakinan Diri (Self } \\
\text { Efficacy) Akademik (X1) }\end{array}$ & .453 & .076 & .499 & 6.004 & .000 \\
\hline Pola Asuh Orang Tua (X2) & .414 & .079 & .433 & 5.218 & .000 \\
\hline
\end{tabular}

a. Dependent Variable: Kemandirian Belajar (Y)

Sumber Data: Diolah Tahun 2018

Berdasakan hasil analisis regresi linier berganda diatas dapat diperoleh suatu persamaan linier sebagai berikut: $Y=\alpha+b_{1} X_{1}+b_{2} X_{2}$ yaitu :

$\mathrm{Y}=11,765+0,453 \mathrm{X}_{1}+0,414 \mathrm{X}_{2}$ 
Dari persamaan linier berganda diatas dapat dijelaskan, bahwa:

a. $\alpha=$ merupakan konstanta yang besarnya 11,765 menyatakan bahwa jika variabel independen (keyakinan diri (self efficacy) akademik dan pola asuh orang tua) sebesar 0 (nol), maka nilai variabel dependen (kemandirian belajar) sebesar 11,765.

b. $b_{1}=0,453$ adalah besarnya koefisien regresi variabel adalah besarnya koefisien regresi variabel bebas keyakinan diri (self efficacy) akademik $\left(\mathrm{X}_{1}\right)$. Artinya, setiap ada penambahan atau kenaikan keyakinan diri (self efficacy) akademik $\left(\mathrm{X}_{1}\right)$ sebesar satu satuan, maka akan menambah variabel terikat hasil kemandirian belajar (Y) sebesar 0,453 dengan anggapan variabel lainnya konstan.

c. $\mathrm{b}_{2}=0,414$ adalah besarnya koefisien regresi variabel adalah besarnya koefisien regresi variabel bebas pola asuh orang tua $\left(\mathrm{X}_{2}\right)$. Artinya, setiap ada penambahan atau kenaikan pola asuh orang tua $\left(\mathrm{X}_{2}\right)$ sebesar satu satuan, maka akan menambah variabel terikat hasil kemandirian belajar (Y) sebesar 0,414 dengan anggapan variabel lainnya konstan.

\section{Uji Hipotesis}

a. Uji t (Parsial)

Uji t digunakan untuk menguji pengaruh variabel $\mathrm{X}_{1}$ dan $\mathrm{X}_{2}$ secara parsial terhadap variabel Y. Hasil uji t adalah sebagai berikut:

\section{Tabel 5. Hasil Uji t}

Coefficients $^{\mathrm{a}}$

\begin{tabular}{|c|c|c|c|c|c|}
\hline \multirow[b]{2}{*}{ Model } & \multicolumn{2}{|c|}{$\begin{array}{l}\text { Unstandardized } \\
\text { Coefficients }\end{array}$} & $\begin{array}{l}\text { Standardized } \\
\text { Coefficients }\end{array}$ & \multirow[b]{2}{*}{$\mathrm{T}$} & \multirow[b]{2}{*}{ Sig. } \\
\hline & B & Std. Error & Beta & & \\
\hline $1 \quad$ (Constant $)$ & 11.765 & 6.183 & & 1.903 & .061 \\
\hline $\begin{array}{l}\text { Keyakinan Diri (Self } \\
\text { Efficacy) Akademik (X1) }\end{array}$ & .453 & .076 & .499 & 6.004 & .000 \\
\hline Pola Asuh Orang Tua (X2) & .414 & .079 & .433 & 5.218 & .000 \\
\hline
\end{tabular}

a. Dependent Variable: Kemandirian Belajar (Y)

Sumber Data: Diolah Tahun 2018

Berdasarkan tabel hasil uji t diatas diperoleh hasil yaitu sebagai berikut:

1) Pengujian hipotesis menujukkan bahwa ada pengaruh yang signifikan antara keyakinan diri (self efficacy) akademik terhadap kemandirian belajar siswa mata pelajaran ekonomi kelas X SMA Negeri 1 Tulungagung tahun pelajaran $2017 / 2018$. Nilai thitung dari $X_{1}$ terhadap Y senilai $t_{\text {hitung }}(6,004)>t_{\text {tabel }}(1,996)$ dan nilai signifikansi $0,00<0,05$ maka Ho ditolak dan Ha diterima.

2) Pengujian hipotesis menujukkan bahwa ada pengaruh yang signifikan antara pola asuh orang tua terhadap kemandirian belajar siswa mata pelajaran ekonomi kelas X SMA Negeri 1 Tulungagung tahun pelajaran 2017/2018. Nilai thitung dari $\mathrm{X}_{2}$ terhadap $\mathrm{Y}$ senilai $\mathrm{t}_{\text {hitung }}(5,218)>\mathrm{t}_{\text {tabel }}(1,996)$ dan nilai signifikansi $0,00<$ 0,05 maka Ho ditolak dan Ha diterima.

b. Uji F (Simultan)

Uji $F$ digunakan untuk menguji pengaruh variabel $\mathrm{X}_{1}$ dan $\mathrm{X}_{2}$ secara bersamasama (simultan) terhadap variabel $\mathrm{Y}$. Hasil uji $\mathrm{F}$ adalah sebagai berikut: 
Tabel 6. Hasil Uji F

ANOVA $^{b}$

\begin{tabular}{|c|c|c|c|c|c|}
\hline Model & Sum of Squares & $\overline{\mathrm{Df}}$ & Mean Square & $\mathrm{F}$ & Sig. \\
\hline $1 \quad$ Regression & 2330.389 & 2 & 1165.194 & 59.073 & $.000^{\mathrm{a}}$ \\
\hline Residual & 1321.554 & 67 & 19.725 & & \\
\hline Total & 3651.943 & 69 & & & \\
\hline
\end{tabular}

a. Predictors: (Constant), Pola Asuh Orang Tua (X2), Keyakinan Diri (Self Efficacy)

Akademik (X1)

b. Dependent Variable: Kemandirian Belajar (Y)

Sumber Data: Diolah Tahun 2018

Berdasarkan hasil analisis data menunjukkan bahwa nilai $F_{\text {hitung }}(59,073)>$ $F_{\text {tabel }}(3,13)$ dan tingkat signifikansi $0,00<0,05$ maka Ho ditolak dan Ha diterima. Hal ini menunjukkan bahwa ada pengaruh yang signifikan antara keyakinan diri (self efficacy) adakemik dan pola asuh orang tua terhadap kemandiran belajar siswa mata pelajaran ekonomi kelas X SMA Negeri 1 Tulungagung tahun pelajaran 2017/2018.

c. Uji Koefisien Determinasi $\left(\mathrm{R}^{2}\right)$

Uji Koefisien Determinasi $\left(\mathrm{R}^{2}\right)$ digunakan untuk mengetahui besarnya pengaruh dari kedua variabel independen yaitu keyakinan diri (self efficacy) adakemik dan pola asuh orang tua terhadap kemandiran belajar siswa mata pelajaran ekonomi kelas X SMA Negeri 1 Tulungagung tahun pelajaran 2017/2018. Maka berikut pengujian melalui program SPSS versi 16.0 for windows yaitu:

Tabel 7. Besar Pengaruh Variabel Bebas terhadap Variabel Terikat

\section{Model Summary}

\begin{tabular}{|l|r|r|r|r|}
\hline Model & \multicolumn{1}{|c|}{$\mathrm{R}$} & R Square & \multicolumn{1}{c|}{$\begin{array}{c}\text { Adjusted R } \\
\text { Square }\end{array}$} & $\begin{array}{c}\text { Std. Error of the } \\
\text { Estimate }\end{array}$ \\
\hline 1 & $.799^{\mathrm{a}}$ & .638 & .627 & 4.441 \\
\hline
\end{tabular}

a. Predictors: (Constant), Pola Asuh Orang Tua (X2), Keyakinan Diri

(Self Efficacy) Akademik (X1)

Sumber Data: Diolah Tahun 2018

Angka $\mathrm{R}$ yang didapatkan 0,799 artinya korelasi antar variabel keyakinan diri (self efficacy) akademik dan pola asuh orang tua terhadap kemandirian belajar siswa mata pelajaran ekonomi kelas X SMA Negeri 1 Tulungagung tahun pelajaran 2017/2018 sebesar 0,799. Hal ini berarti menjadi hubungan yang terlalu erat karena nilai mendekati 1.

Nilai $\mathrm{R}^{2}$ ( $R$ Square) sebesar 0,638 artinya persentase sumbangan pengaruh keyakinan diri (self efficacy) akademik dan pola asuh orang tua terhadap kemandirian belajar siswa mata pelajaran ekonomi kelas X SMA Negeri 1 Tulungagung tahun pelajaran 2017/2018 sebesar 63,8\%, sedangkan sisanya $36,2 \%$ dipengaruhi oleh variabel lain yang tidak dimasukkan dalam penelitian ini.

d. Sumbangan dari Variabel Bebas Terhadap Variabel Terikat

1) Sumbangan Relatif

Keyakinan diri (self efficacy) akademik memberikan sumbangan relatif sebesar 50,9\% dan pola asuh orang tua memberikan sumbangan relatif $49,1 \%$ terhadap kemandirian belajar dengan total 100\%. Dengan Sumbangan yang diberikan, maka dapat diartikan bahwa keyakinan diri (self efficacy) akademik 
dan pola asuh orang tua memiliki peran yang dominan dalam menetukan kemandirian belajar.

2) Sumbangan Efektif

Keyakinan diri (self efficacy) akademik memberikan sumbangan efektif sebesar $32,47 \%$ dan pola asuh orang tua memberikan sumbangan efektif sebesar $31,33 \%$ terhadap kemandirian belajar dengan total sebesar $63,8 \%$. Hal ini menunjukkan bahwa keyakinan diri (self efficacy) akademik dan pola asuh orang tua mampu mempengaruhi dan menyumbang kemandirian belajar sebesar $63,8 \%$. Sisanya sebesar $36,2 \%$ adalah sumbangan lain yang disebabkan oleh variabel diluar penelitian.

\section{B. Pembahasan}

1. Pengaruh Keyakinan Diri (Self Efficacy) Akademik terhadap Kemandirian Belajar Siswa Mata Pelajaran Ekonomi Kelas X SMA Negeri 1 Tulungagung Tahun Pelajaran 2017/2018

Menurut Hasbullah \& Boon (2015: 3) "kepercayaan atau keyakinan diri akademik adalah keyakinan yang dirasakan oleh seorang individu tentang kemampuannya dalam mengerjakan tugas-tugas keilmuan yang membentuk perilaku yang relevan”. Menurut Sunawan (2005, seperti dikutip Widiyanto, 2013: 4) menyatakan bahwa berbagai studi menunjukkan self efficacy berpengaruh terhadap motivasi, keuletan dalam menghadapi kesulitan dari suatu tugas dan prestasi belajar.

Berdasarkan analisis data dengan perangkat lunak (software) Stastistical Package for Social Science (SPSS) for Windows version 16.0 dapat disimpulkan bahwa ada pengaruh yang signifikan antara keyakinan diri (self efficacy) akademik terhadap kemandirian belajar siswa mata pelajaran ekonomi kelas X SMA Negeri 1 Tulungagung tahun pelajaran 2017/2018. Nilai thitung dari $\mathrm{X}_{1}$ terhadap $\mathrm{Y}$ senilai $\mathrm{t}_{\text {hitung }}(6,004)>\mathrm{t}_{\text {tabel }}(1,996)$ dan nilai signifikansi $0,00<0,05$ maka Ho ditolak dan Ha diterima yang berarti signifikan. Keyakinan diri (self efficacy) akademik memberikan sumbangan efektif sebesar 32,47\%. Artinya, variabel keyakinan diri (self efficacy) akademik tersebut memberikan kontribusi sebesar 32,47\% terhadap kemandirian belajar. Penelitian ini dapat disimpulkan berdasarkan perhitungan data yang diperoleh bahwa peserta didik yang memiliki keyakinan diri (self efficacy) akademik baik lebih percaya diri dalam menyelesaikan tugas-tugas yang dihadapinya sebab peserta didik tersebut yakin akan kemampuan yang dimilikinya maka akan memungkinkan peserta didik kelas X memiliki kemandirian belajar lebih baik dan begitu pula sebaliknya.

Sejalan dengan hasil penelitian yang dilakukan Apriani Kartika Sari, Muhsin, Fahrur Rozi (2017) yang berjudul "Pengaruh Motivasi, Sarana Prasarana, Efikasi Diri, dan Penyesuaian Diri terhadap Kemandirian Belajar". Dari hasil penelitian tersebut dapat diambil kesimpulan bahwa ada pengaruh antara motivasi belajar, sarana dan prasarana pembelajaran, efikasi diri dan penyesuaian diri di sekolah terhadap kemandirian belajar siswa administrasi perkantoran SMK YPE Nusantara Slawi. Selain itu penelitian ini juga sejalan dengan hasil penelitian yang dilakukan Ika Aprilia, Sri Witurachmi dan Nurhasan Hamidi (2017) yang berjudul "Pengaruh Self-Efficacy dan Motivasi Berprestasi terhadap Kemandirian belajar Siswa pada Mata Pelajaran Produktif Akuntansi”. Berdasarkan hasil penelitian tersebut dapat disimpulkan bahwa ada pengaruh yang positif dan signifikan Self-Efficacy dan motivasi berprestasi terhadap kemandirian belajar siswa pada mata pelajaran produktif akuntansi. Penelitian ini juga didukung hasil penelitian yang dilakukan Venny Febriani (2016) yang berjudul "Pengaruh Efikasi Diri dan Regulasi Diri 
terhadap Kemandirian Belajar Siswa Pada Mata Pelajaran IPS”. Berdasarkan hasil penelitian tersebut dapat disimpulkan bahwa efikasi diri dan regulasi diri berpengaruh signifikan terhadap kemandirian belajar siswa.

\section{Pengaruh Pola Asuh Orang Tua terhadap Kemandirian Belajar Siswa Mata Pelajaran Ekonomi Kelas X SMA Negeri 1 Tulungagung Tahun Pelajaran 2017/2018}

Menurut Desywidowati et al (2013: 6) pola asuh orang tua adalah keseluruhan interaksi antara orang tua dengan anaknya, dimana orang tua bermaksud menstimulasi anaknya dengan mengubah tingkah laku, pengetahuan serta nilai-nilai yang dianggap paling tepat oleh orang tua, agar anak menjadi mandiri, tumbuh dan berkembang secara sehat dan optimal. Pendapat Nurwahyuni (2013: 68-69) pola asuh orang tua merupakan faktor yang dapat berpengaruh terhadap kemandirian belajar siswa karena lingkungan keluarga yang di dalamnya terdapat orang tua yang berperan penuh dan memberi pendidikan awal sebelum menempuh pendidikan formal. Sebelum peserta didik memasuki suatu sekolah, peserta didik sudah mendapatkan pendidikan dari orang tuanya.

Berdasarkan analisis data dengan perangkat lunak (software) Stastistical Package for Social Science (SPSS) for Windows version 16.0 dapat disimpulkan ada pengaruh yang signifikan antara pola asuh orang tua terhadap kemandirian belajar siswa mata pelajaran ekonomi kelas X SMA Negeri 1 Tulungagung tahun pelajaran 2017/2018. Nilai thitung dari $\mathrm{X}_{2}$ terhadap $\mathrm{Y}$ senilai $\mathrm{t}_{\text {hitung }}(5,218)>\mathrm{t}_{\text {tabel }}(1,996)$ dan nilai signifikansi $0,00<0,05$ maka Ho ditolak dan Ha diterima yang berarti signifikan. Pola asuh orang tua memberikan sumbangan efektif sebesar $31,33 \%$. Artinya, variabel pola asuh orang tua tersebut memberikan kontribusi sebesar 31,33\% terhadap kemandirian belajar. Penelitian ini dapat disimpulkan berdasarkan perhitungan data yang diperoleh bahwa dengan adanya pola asuh orang tua yang baik pada anaknya maka kemandirian belajar yang dijalani peserta didik kelas $\mathrm{X}$ juga akan baik dan begitu pula sebaliknya.

Sejalan dengan hasil penelitian yang dilakukan dilakukan Fahrizal Efendhi (2014) yang berjudul "Pengaruh Pola Asuh Orang Tua terhadap Kemandirian dalam Belajar Siswa". Berdasarkan hasil penelitian tersebut dapat disimpulkan bahwa ada pengaruh yang signifikan antara pola asuh orang tua terhadap kemandirian siswa dalam belajar. Selain itu penelitian ini juga sejalan dengan hasil penelitian yang dilakukan Enda Dian Rahnawati (2013) yang berjudul "Pengaruh Pola Asuh Orang Tua terhadap Kemandirian Belajar Siswa Kelas XI TSM SMK N 8 Purworejo". Berdasarkan hasil penelitian tersebut dapat disimpulkan bahwa pola asuh orang tua memberikan pengaruh yang signifikan terhadap kemandirian belajar.

\section{Pengaruh Keyakinan Diri (Self Efficacy) Akademik dan Pola Asuh Orang Tua terhadap Kemandirian Belajar Siswa Mata Pelajaran Ekonomi Kelas X SMA Negeri 1 Tulungagung Tahun Pelajaran 2017/2018}

Menurut D. Z. Putri (2015: 5) mengemukakan "kemandirian dalam belajar dapat diartikan sebagai aktivitas belajar dan berlangsungnya lebih didorong oleh kemauan sendiri, pilihan sendiri dan tanggung jawab sendiri dari siswa. Siswa yang memiliki kemandirian belajar, tidak akan terus menerus tergantung pada materi yang diberikan oleh guru dikelas".

Menurut Haris Mudjiman (2007, seperti dikutip Febriani, 2016: 2.356) peserta didik yang memiliki kemandirian belajar cenderung lebih aktif dibandingkan peserta didik yang kurang memiliki kemandirian belajar. Hal ini terjadi karena peserta didik dengan 
kemandirian belajar yang tinggi selalu memiliki inisiatif untuk mencari pengalaman baru melalui kegiatan belajar dengan atau tanpa bantuan dari guru professional.

Pada umumnya peserta didik yang memiliki kemandirian belajar rendah lebih memilih jalan pintasan yang bersifat instans atau cenderung melakukan kecurangan akademik seperti copy paste dan menyontek (baik ujian maupun dalam mengerjakan tugas) pekerjaan temannya untuk mencapai tujuan dalam belajar. Menurut Hasan Basri (2000, seperti dikutip Rianawati, 2014) kemandirian belajar dipengaruhi oleh beberapa faktor yaitu faktor yang terdapat di dalam dirinya sendiri (faktor endogen) dan faktor dari luar dirinya sendiri (faktor eksogen). Faktor endogen (internal) adalah semua pengaruh yang bersumber dari dalam diri sendiri, seperti keadaan keturunan dan konstitusi tubuhnya sejak dilahirkan dengan segala perlengkapan yang melekat padanya. Faktor eksogen (eksternal) adalah semua keadaan atau pengaruh yang berasal dari luar dirinya, sering juga disebut faktor lingkungan.

Berdasarkan analisis data dengan perangkat lunak (software) Stastistical Package for Social Science (SPSS) for Windows version 16.0 dapat disimpulkan bahwa ada pengaruh yang signifikan antara keyakinan diri (self efficacy) adakemik dan pola asuh orang tua terhadap kemandiran belajar siswa mata pelajaran ekonomi kelas X SMA Negeri 1 Tulungagung tahun pelajaran 2017/2018. Hal ini berdasarkan nilai $F_{\text {hitung }}(59,073)>F_{\text {tabel }}$ $(3,13)$ dan tingkat signifikansi $0,00<0,05$ maka Ho ditolak dan Ha diterima yang artinya signifikan. Nilai $\mathrm{R}^{2}$ ( $R$ Square) sebesar 0,638 artinya persentase sumbangan pengaruh keyakinan diri (self efficacy) akademik dan pola asuh orang tua terhadap kemandirian belajar siswa mata pelajaran ekonomi kelas X SMA Negeri 1 Tulungagung tahun pelajaran 2017/2018 sebesar $63,8 \%$, sedangkan sisanya $36,2 \%$ dipengaruhi oleh variabel lain yang tidak dimasukkan dalam penelitian ini. Penelitian ini dapat disimpulkan berdasarkan perhitungan data yang diperoleh bahwa dengan adanya keyakinan diri (self efficacy) akademik yang baik dan pola asuh orang tua yang baik pada peserta didik maka kemandirian belajar yang dijalani peserta didik kelas $\mathrm{X}$ juga akan baik begitu pula sebaliknya.

\section{PENUTUP}

\section{A. Simpulan}

Berdasarkan hasil penelitian, dapat disimpulkan beberapa hal sebagai berikut:

1. Ada pengaruh yang signifikan antara keyakinan diri (self efficacy) akademik terhadap kemandirian belajar siswa mata pelajaran ekonomi kelas X SMA Negeri 1 Tulungagung tahun pelajaran 2017/2018. Hal ini terbukti bahwa nilai $t_{\text {hitung }}$ dari $\mathrm{X}_{1}$ terhadap Y senilai $t_{\text {hitung }}(6,004)>t_{\text {tabel }}(1,996)$ dan nilai signifikansi $0,00<0,05$ maka Ho ditolak dan Ha diterima. Keyakinan diri (self efficacy) akademik memberikan sumbangan efektif sebesar $32,47 \%$ terhadap kemandirian belajar.

2. Ada pengaruh yang signifikan antara pola asuh orang tua terhadap kemandirian belajar siswa mata pelajaran ekonomi kelas X SMA Negeri 1 Tulungagung tahun pelajaran 2017/2018. Hal ini terbukti bahwa nilai thitung dari $\mathrm{X}_{2}$ terhadap Y senilai thitung $(5,218)>$ $\mathrm{t}_{\text {tabel }}(1,996)$ dan nilai signifikansi $0,00<0,05$ maka Ho ditolak dan Ha diterima. Pola asuh orang tua memberikan sumbangan efektif sebesar $31,33 \%$ terhadap kemandirian belajar.

3. Ada pengaruh yang signifikan antara keyakinan diri (self efficacy) akademik dan pola asuh orang tua terhadap kemandirian belajar siswa mata pelajaran ekonomi kelas X SMA Negeri 1 Tulungagung tahun pelajaran 2017/2018. Hal ini terbukti berdasarkan hasil analisis data menunjukkan bahwa nilai $F_{\text {hitung }}(59,073)>F_{\text {tabel }}(3,13)$ dan tingkat signifikansi $0,00<0,05$ maka Ho ditolak dan Ha diterima yang artinya signifikan. 
Keyakinan diri (self efficacy) akademik dan pola asuh orang tua mampu mempengaruhi dan menyumbang kemandirian belajar sebesar $63,8 \%$.

\section{B. Saran}

Saran yang dapat diberikan yaitu: (1) Bagi Siswa, Hendaknya keyakinan diri (self efficacy) akademik siswa harus ditingkatkan dalam rangka mewujudkan kemandirian belajar yang baik khususnya pada mata pelajaran ekonomi. Sehingga dengan adanya keyakinan pada diri siswa, siswa lebih percaya diri dalam mengerjakan atau menyelesaikan tugas-tugas akademik yang dihadapinya sebab siswa tersebut yakin akan kemampuan yang dimilikinya maka akan memungkinkan siswa tersebut memiliki kemandirian belajar lebih baik. (2) Bagi Guru, Hasil penelitian ini dapat digunakan sebagai pertimbangan untuk meningkatkan keyakinan diri (self efficacy) akademik dan pola asuh orang tua khususnya pada mata pelajaran ekonomi sehingga kemandirian belajar dapat terwujud dan prestasi siswa menjadi lebih baik. (3) Bagi STKIP PGRI Tulungagung, Hasil penelitian ini dapat digunakan untuk menambah pengetahuan dalam penelitian Program Studi Pendidikan Ekonomi yang berkaitan dengan keyakinan diri (self efficacy) akademik, pola asuh orang tua dan kemandirian belajar dalam proses pembelajaran. (4) Bagi Peneliti Lain, Hendaknya peneliti lain melakukan penelitian dengan variabel-variabel lain diluar variabel yang digunakan peneliti saat ini, dikarenakan masih banyak variabel-variabel yang mempengaruhi kemandirian belajar yang belum diteliti.

\section{DAFTAR PUSTAKA}

Aprilia, I., Witurachmi, S., \& Hamidi, N. (2017). Pengaruh Self-Efficacy dan Motivasi Berprestasi terhadap Kemandirian Belajar Siswa pada Mata Pelajaran Produktif Akuntansi. Jurnal Tata Arta UNS, 3(1), 134-149.

Arikunto, Suharsimi. 2010. Prosedur Penelitian Suatu Pendekatan Praktik. Jakarta: PT. Rineka Cipta.

Desywidowati, N., Rohmad, Z., \& CH, S. R. (2013). Hubungan antara Pola Asuh Orang Tua, Motivasi Belajar, Kedewasaan dan Kedisiplinan Siswa dengan Prestasi Belajar Sosiologi Siswa Kelas XI SMA Negeri 1 Sidoharjo Wonogiri, 1-25.

Efendhi, F. (2014). Pengaruh Pola Asuh Orang Tua terhadap Kemandirian dalam Belajar Siswa. Jurnal Ilmiah Pendidikan Bimbingan Dan Konseling, 50-59.

Febriani, V. (2016). Pengaruh Efikasi Diri dan Regulasi Diri Terhadap Kemandirian Belajar Siswa pada Mata Pelajaran IPS. Jurnal Pendidikan Guru Sekolah Dasar, 24(5), 2.3552.364.

Fredrika, M. E., \& Prasetyawati, W. (2013). Gambaran Kecurangan Akademik pada Siswa Kelas 6 Sekolah Dasar, 1-22.

Hasbullah, \& Boon, Y. (2015). Keyakinan Diri sebagai Dimensi Kepribadian Guru Di Sekolah Menengah Atas Negeri Makassar. Jurnal of EST, 1(3), 1-9.

Hasyim, E. R. (2013). Pengaruh Efikasi Diri, Kreativitas dan Iklim Kelas Terhadap Kemandirian Belajar Siswa Kelas X Program Keahlian Teknik Instalasi Tenaga Listrik Smk Negeri 2 Yogyakarta.

https://www.bps.go.id/

Murdiansyah, I., Sudarma, M., \& Nurkholis. (2017). Pengaruh Dimensi Fraud Diamond Terhadap Perilaku Kecurangan Akademik (Studi Empiris Pada Mahasiswa Magister Akuntansi Universitas Brawijaya). Jurnal Akuntansi Aktual, 4(2), 121-133.

Nurwahyuni. (2013). Pengaruh Konsep Diri Siswa dan Pola Asuh Orang Tua terhadap Kemandiarian Belajar Siswa SMP Di Palu Sulawesi Tengah. Tri Sentra Jurnal Ilmu 
Pendidikan, 2(4), 67-77.

Putri, D. Z. (2015). Pengaruh Keyakinan pada Kemampuan Diri Sendiri (Efikasi Diri) terhadap Kemandirian Belajar Siswa Kelas XI SMK Bhakti Mulia Pare Kediri 2014 / 2015, 1-8.

Rahnawati, E. D. (2013). Pengaruh Pola Asuh Orang Tua terhadap Kemandirian Belajar Siswa Kelas XI TSM SMK N 8 Purworejo. OIKONOMIA, 2(4), 319-324.

Rianawati. (2014). Internalisasi Karakter Kemandirian melalui Pembelajaran Konstruktif Di Perguruan Tinggi.

Sari, A. K., Muhsin, \& Rozi, F. (2017). Pengaruh Motivasi, Sarana Prasarana, Efikasi Diri, dan Penyesuaian Diri terhadap Kemandirian Belajar. Economic Education Analysis Journal, 6(3), 923-935.

Sugiyono. 2015. Metode Penelitian Pendidikan. Bandung: Alfabeta.

Sujarweni, Wiratna. 2014. Metodologi Penelitian. Yogyakarta: Pustaka Baru Press.

Widianto, Y. H. (2016). Pengaruh Pola Asuh Orang Tua Authoritative terhadap Kemandirian Belajar pada Siswa Kelas X SMA Negeri 1 Pakem.

Widiyanto, A. (2013). Pengaruh Self-Efficacy dan Motivasi Berprestasi Siswa terhadap Kemandirian Belajar Mata Pelajaran K3 (Keselamatan dan Kesehatan Kerja) Di SMK N 2 Depok, 3. 